Please do not remove this page

RMIT

UNIVERSITY

\title{
From shadowy zone to daily routine: Finance culture in Australia
}

Greenfield, Cathy; Williams, Peter

https://researchrepository.rmit.edu.au/esploro/outputs/9921862047101341/filesAndLinks?institution=61RMIT_INST\&index=null

Greenfield, C., \& Williams, P. (2013). From shadowy zone to daily routine: Finance culture in Australia. Topia: Canadian Journal of Cultural Studies, 30-31, 103-122.

https://researchrepository.rmit.edu.au/discovery/fulldisplay/alma9921862047101341/61RMIT_INST:Resea rchRepository

Document Version: Accepted Manuscript 
Thank you for downloading this document from the RMIT Research Repository.

The RMIT Research Repository is an open access database showcasing the research outputs of RMIT University researchers.

RMIT Research Repository: http://researchbank.rmit.edu.au/

\section{Citation:}

Greenfield, C and Williams, P 2013, 'From shadowy zone to daily routine: Finance culture in Australia', Topia: Canadian Journal of Cultural Studies, vol. 30-31, pp. 103-122.

See this record in the RMIT Research Repository at:

https://researchbank.rmit.edu.au/view/rmit:26765

Version: Accepted Manuscript

Copyright Statement: (C) N/A

Link to Published Version:

http://topia.journals.yorku.ca/index.php/topia/article/view/38423 
From Shadowy Zone to Daily Routine: Finance Culture in Australia

Cathy Greenfield \& Peter Williams

Abstract

This paper contributes to accounts of the role of finance and financialization in Australia. Starting from the perspective of recent signs of disenchantment with financialization it describes how contemporary instabilities in a dominant finance-led regime of government are difficult to yoke to wider projects for change, given the normalization of finance culture in Australia. This normalization is described and analysed, paying particular attention to the part various media in Australians' acquisition of a finance rationality. While the paper's main concern is to add to the historicization of finance, finance culture, its various actors, rationality and its technologies as something other than the natural habitat of people in the 21 st century, it does so from the current problem of what counter-inscriptions and arguments face in building constituencies for alternative and oppositional policies concerning finance.

KEYWORDS Financialization, finance rationality, finance culture, media, Australia

\section{Introduction: studying finance culture in Australia}

In fifteen years of studying the settling in of financialization in Australia, piecing together its amalgam of rationalities, technologies, rhetorics, policies, actors and alliances and considering its consequences for different social groups and institutions, it has seemed to us to have been more or less without challenge in the late $1990 \mathrm{~s},{ }^{1}$ then suffered a period of crisis-driven disenchantment, recovering to the present moment with its less spectacular skirmishes and contestations around the priority of finance. For us the problem of financialization-how it places people's work and everyday lives in ways routinely beyond their possible control—is joined by considering how these current contestations may fare, and we turn to these in the 
paper's conclusion. The bulk of the paper locates these within the longer run of finance culture in Australia. After establishing what is entailed in financialization, we give a brief indication of recent disenchantments before turning to the longer history of its late twentieth-century and early twenty-first-century dominance. Throughout, attention is on the role of finance and financialization in Australia, on the understanding that the neoliberal restructuring engineered to secure a 'finance-led accumulation regime' — with its 'giant mergers, capital mobility between countries, pressures on corporate governance [and] diffusion of equity among a larger fraction of population' (Boyer 2000, p 116), or (less narrowly and epochally defined) with its 'new form of competition... a change in orientation towards financial results but also a kind of speed up in management work' (Froud et al 2000, p.104) — is at once familiar as an internationally pursued strategy and always local in how it is achieved and experienced.

To do this we draw on resources that deal with various though especially Anglophone economies and societies and which foreground the cultural and communicative aspects of economies. A diverse scholarship has provided this kind of perspective over the last two decades — in the field of cultural economy (for example, Amin \& Thrift 2004; de Goede 2005; Martin 2002), as well as in economics and finance (for example, Best 2005; Callon 1998; Gibson-Graham 1996; MacKenzie 2006), and in international political economy (for example, Langley 2002, 2008; Leyshon and Thrift 1997; Thrift 1998, 2001; Williams 2000). ${ }^{2}$ Across a range of different debates and topics, this literature takes into account the constitutive (or performative) ${ }^{3}$ role of discourses, frameworks or rhetorics in the organization and undertaking of economic activity and in this spirit has also paid attention to diverse communication technologies and their various contributions to historical or contemporary economic formations. This literature is marked by its rebuttal of orthodox economic's abstraction of economic activity from politics and the political, and thus on two 
counts assists a non-reductive analysis of economic matters, a socially and culturally informed political economy.

\section{Elements of Financialization-Transnational and Local}

This is how we approach financialization, arguing that this growth regime centred on increase in equity (ownership interest possessed by shareholders in a corporation), or shareholder value, entails a definite cultural and communicative dimension (that is, concepts, doctrines and rationalities, computerization, ICTs, persuasion, media production), which we foreground in the following account. The concept of shareholder value works within the wider neoclassical economic doctrine that the market is the best — most efficient — determinant of the distribution of resources and return. Its specific contribution is to bring the discipline of the market deep into corporate governance by redefining the managers of corporations as simply the agents of the principle actors, the shareholders, and, from the 1970s, persuading them away from established principles of retaining profits, employees and reinvesting in their companies.

Crudely put, with the doctrine of shareholder value the driver of economic growth became expansion of ownership, a substantially different situation from the post-war Fordist growth regime, where consumption, investment, and enterprise growth was fuelled by the yoking of productivity gains and real wage increases. In the finance-led regime, a 'self-fulfilling macro-economic dynamic' (Aglietta 2000: 155) links the requirement of shareholder value to financial return, to rising share prices, to incentives for more investment in stocks, and, in households, to consumption driven not only by disposable income but by capital gains. 
Central to this dynamic was the channelling of savings into the capital market through the expansion of defined contribution pension plans - in Australia, through the introduction of award superannuation in 1986 and compulsory superannuation in 1992 (Broadbent et al 2006). These developments made available new funds for investment and ensured a growing number of households were more directly and substantially plugged into equity markets than ever before. By 2004, '55 per cent of adult Australians, or 8 million people, [held] shares in their investment portfolio...the highest reported level of retail share ownership in the world' (Weekes, Age, 30 April, $2005,5)$.

The key institutional driver of financialization has been deregulation, exercised as a transformative policy intervention framing markets in particular ways. In Australia, it was successive Labor Governments (1983-1996) that introduced deregulation and developed neoliberal governance, before it took an increasingly social conservative character under the Howard Coalition Government (1996-2007). The Hawke Labor Government implemented a range of changes in the finance sector-from loosening government regulations on stockbrokers' commissions, interest rates on deposits and loans, and conditions on ownership and the international mobility of capital—which were mostly in place by the end of 1984 and all by 1986. The Labor Government also began the privatisation of major public assets, with many more basic utilities privatised by various State Governments. This early instalment of a deregulated finance sector set the pace and model for longer-term remaking of a range of social policies in terms of market discipline, competition and individuals self-funding their needs for services previously seen as public goods. Characterized as a 'revolution' in Australian finance (Kelly 1992: 79), the changes opened up Australia to international finance markets and enabled the accelerating international financial integration that would start to be described as globalization. 
While this globalization of financial markets is often presented as an unstoppable phenomenon, the inevitable result of new communication technology and market developments, the financial deregulation that underpins it was the outcome of definite policy decisions made by national governments, persuaded by ideological advocates ${ }^{4}$ and not simply the evolution of market forces. It was the success of such advocacy that produced the shift away from the restrictions of the Bretton Woods financial order which had purposefully neutralized the power of international capital after WWII (Leyshon and Thrift 1997: 281). Understood in this way, abandoning capital controls in the 1970s and ' 80 s can be seen not so much as ushering in an unprecedented period of finance-led capitalism but something more like a return tothough not exact repetition of - the financial environments that prevailed at the end of the $19^{\text {th }}$ and first part of the $20^{\text {th }}$ century. Whatever the virtue or limits of such comparisons, placing financialization historically defrays hubris about the 'revolutionary' character of the current period.

What was different at the end of the $20^{\text {th }}$ century was the massively increased volume and speed of global flows of finance capital, the pervasive influence of the decisions and calculations of finance market actors across the entire range of government and other organizational policies, and the massive growth of financial risk generated by the removal of a rigidly imposed gold standard within which international capital had been required to flow. The development of mechanisms for hedging against this risk through burgeoning markets in derivatives was one result, commodifying risk into differentiated contractual packages of exposure through the practice of securitization, the assembling of risk into standard categories of financial products (Bryan and Rafferty 2006). And accompanying such mechanisms and practices was a shift in emphasis from an insider to an outsider model of finance. The older, insider model involved bank-based evaluation of the asset price and risk of private economic 
activities: an outsider model evaluates the price and risk of those same activities through what the French regulationists, Aglietta and Breton, have called 'the public opinion of financial markets' (2001: 436). Where banks relied on detailed, personal knowledge of a firm or an individual borrower, the outsider model involves a statistical apparatus to infer likely returns for standard categories of financial products.

One such product, by now well-known in the wake of the GFC, is the mortgage bond. Invented in the 1980s as investment products for Wall Street by depersonalizing home mortgages and aggregating them in their several thousands to make up millions of homogenized pools of particular characteristics (Lewis 1989: 85), this derivative could then be traded throughout the world, binding home borrowers and multiple investors located in different geographies into new relations. To this reshaping, or 'globalization' of space, forward-based derivatives add the reconfiguration of times, connecting the presents and futures of different populations through the expectations of traders about future events in diverse places (Pryke and Allen 2000: 273). In Australia, Wingecarribee and Parkes Shire Councils in New South Wales were just two of the investors that audiences heard about as complexly yoked to mortgagees in the U.S. at the time of the sub-prime crisis, through their investment in bespoke financial products those investors didn't understand (Federal Court of Australia 2012).

One condition enabling calculations of probable risk and return on the pooling of debt (such as home mortgages) was computerization. The affordances of new information and communication technologies were necessary for the widespread uptake of the outsider model: without them, 'relatively few assets were marketized because the conditions necessary to apply the statistical methodology of evaluation were not met 
for a large range of private debts' (Aglietta and Breton 2001: 437). And with these new ways of 'knowing' came different actors. The outsider model shifted the role of the traditional bank manager from centre stage in favour of the worker-shareholder and their professional investment manager. Making these personalities central in the new finance culture meant people being readied to seek out an investment adviser or to start to think about themselves as potential shareholders. These two figures featured in a rising tide of finance advertising and broader publicity (Greenfield \& Williams 2001). One example in Australia was the finance bank Banker's Trust (BT) turn of the century campaign and its humanizing, personalizing strategy. The television arm of the campaign ran a series of advertisements, each one profiling an individual finance adviser-youngish, personable, informal but professional, talking about his or her job. Viewers got the impression of the personal satisfaction these likeable people derived from their careful attention to their clients' needs, or from the interesting intricacies of superannuation or other finance areas. So what might have seemed an alien or daunting world of high finance and expertise was presented as everyday conversation with knowledgeable but approachable persons, and finance and perplexing financial products as in fact a pleasant and reassuring world, or one that can be, with BT.

Thus, amongst other elements, financialization includes media promotion of the increasing significance of finance organizations, services and products in people's lives. In Australia, as elsewhere (Parsons 1989), the decisions of public, commercial and specialized media organizations, themselves players in finance markets, helped produce a rise in attention to and coverage of finance. During the 1980s a number of personal finance magazines were launched in Australia (Toohey 1994: 234) and by the 1990s Australian television audiences were watching series like Money, Healthy Wealthy and Wise, Your Money and Your Life, The Bottom Line-popular television for the first time dedicated to finance and money. If by the 2000s (and a government- 
induced housing boom) these finance-specific shows were replaced by programs about owning property (Hot Property, Auction, The Block), and specific market information returned to business-oriented programs and routine current affairs segments, it marked not a disappearance but a naturalization of neoliberal economic discourses and dispositions. By the $21^{\text {st }}$ century in Australia investment advice, superannuation, insurance, home mortgages, consumer credit, specialized retirement advice, financial counselling, Internet banking and stock-market trading, were all thoroughly routinized topics of consumer conversation and knowledge.

\section{Dominance and disenchantments}

By the early years of this century, finance rationality and culture in Australia seemed securely dominant. It underpinned then Prime Minister Howard's agenda of turning the country into the world's leading shareholder democracy, a 'nation of shareholders' (Howard 1999). The agenda had much in common, in terms of neoliberal doctrine of choice and individual empowerment, with the Bush administration's early 2000s vision of an 'ownership society' (Glastris 2005), and was tellingly characterized in this British commentator's view of Howard's re-election in 2004:

John Howard's message throughout the campaign has been: this is not really a country - it is an $\$ 800$ billion corporation and the CEO and board of directors are doing a first-rate job. This is not really an election - rather an extraordinary general meeting to confirm the directors' remuneration packages. (Mant 2004)

But for a short period in 2008-2009 the normalized finance culture of neoliberal practices and assumptions — around the desirability, inevitability and productivity of prioritizing global finance capital flows; around the need for deregulation and the retreat of the State, except in ensuring the existence of markets; around freedom of choice as the hallmark of aspirational, self-responsible individuals qua rational 
sovereign consumers - was thrown open to query, inspection, retrospective reassessment and some backtracking by prominent advocates. Financialization had established the conditions for the global financial crisis. As it unfolded, the newly elected Australian Rudd Labor Government swiftly adopted Keynesian crisis measures, an AUD \$45 billion fiscal stimulus preventing the consequences of recession and high unemployment that occurred in many other countries.

As news and current affairs programs sought to explain the crisis, more heterodox discussion of economic affairs than had predominated for some years, even apparent cracks in the established neoliberal truth regime, was evident as explicit arguments were made in daily media—not just academic circles—about the fragility and unwelcome consequences of neoliberal economic arrangements. In early 2009 the Prime Minister wrote an essay denouncing neoliberalism and 'extreme capitalism' (though not financialization; Rudd's critique was focussed on the ideology of greed rather than neoliberal technologies of governing (Dean 2009)), reprinted later the same year as part of a symposium of views in the Monthly, a magazine of debate on Australian society, politics and culture (Symposium 2009). As elsewhere in financialized economies, the possible enormity of the GFC seemed to point to a shifting in the political imaginary. Where an 'economic politics' (du Gay 2004) had since the late 1980 s displaced the political and with it the very possibility of different social arrangements than those dictated by the short termism of shareholder value and the self-evident parameters of global competitiveness, suddenly these neoliberal verities were contestable again.

More than through Rudd's erudite essay, however, widespread disenchantment with the consequences of financialization was communicated at the time by the quarterly or half-yearly reports on fund balances sent to superannuants or those workers 
approaching retirement age. These groups found the deep exposure of most Australian superannuation funds to the equities market (in 2013 still the highest exposure in the world) had transmitted losses from the GFC to the bases on which they had planned, or were planning, their retirement. Compulsory superannuation, the privatization of established provisions for social security which had delivered a huge boost to the finance sector in Australia when introduced in 1992, now faced many Australians with the uncertainty and risk that is the downside to the attraction of 'effortless enrichment' (Pryke and Allen 2000: 281).

A different and more public staging of disenchantment came from Occupy Australia, which, as elsewhere, contested the assumption that neoliberal finance arrangements necessarily benefitted all or were irreplaceable. Also as elsewhere (Froud et al 2011), the potential of Occupy's questioning of finance-led economies stopped well short of generating an organizational agenda, and the persuasiveness of its arguments was hampered by —or at least attacked in terms of — Australia's status as a 'miracle economy' (Symons 2010), with only one-quarter of negative economic growth during the GFC and unemployment peaking at 5.8\%. Ongoing debate over the reasons for 'the miracle economy' — swift Keynesian fiscal stimulus, or more prudent and restrained financial deregulation than elsewhere, or in fact more thoroughgoing implementation of neoliberal withdrawal of the State - probably helped muddy whatever climate of opinion might have supported the Occupy cause.

In any case, for disenchantment to be articulated and to provide the basis for a challenge to the 'financialized imagination' of Australians - a way of making sense of their interests and their future only through the terms of private ownership — was always going to be difficult. What had happened to finance culture in Australia from the 1970 s to the end of the century mitigated against its easy dislodging. 


\section{From Shadowy Zone to Daily Routine}

Finance has always had its own, specialized culture. The City of London and Wall Street were names that throughout the nineteenth and the better part of the twentieth century conjured up a world of establishment wealth, rarefied activity, in-house knowledge, and restricted access: a world 'traditional and stuffy, with codes of conduct reflecting a closely bound world of long-established firms and personal relationships built on trust and whose banking halls and...exteriors displayed solidity, permanence and discreet luxury' (Whimster and Budd 1992: 1). In Australia, Collins Street in Melbourne and Macquarie Street in Sydney were versions of the same. In 1971, an editorial in the Financial Review welcomed a proposed securities industry watchdog as answering the need for 'a gust of democratic air through the fetid, windowless corridors of the ancient clubs peopled by company directors and stockbrokers' (Financial Review, 1 April, 1971, 2). It was not a world that was part of everyone's everyday and it was not assumed many people — beyond those already 'in the know'—would be interested in it. As the historian Braudel put it, finance was a 'shadowy zone', where 'certain groups of privileged actors are engaged in circuits and calculations that ordinary people knew nothing of' (in Arrighi 1994: 24).

This world changed decisively in the 1980s with a booming finance environment associated with excess - excessive profit, excessive risk-taking, excessive appetites; excesses which got their popular, fictive rendition in the iconic Hollywood movie Wall Street. But as well as such fictional entertainments, a general upswing in media coverage of finance deals, issues, and players made it harder for people to be as oblivious to the 'shadowy zone' as they had been. In Australia, by the turn of the century film and television producers and publishers were prepared to bet on popular 
audiences for narratives built around the role of finance. The television miniseries The Farm (2001) told of the financial and personal ruin of a pastoralist family who followed bank advice to take out a loan in Swiss francs, as had many Australians in similar positions in 1985. It showed the entanglement of ordinary lives with the consequences of a run on the Australian dollar. Expatriate Australian author Kate Jennings published Moral Hazard (2002), a novel that unravelled the mysteries of the world of 'quants' and high finance through the eyes of a Wall Street novice, a woman thrown into working for an investment bank to pay for her husband's medical treatment. In 2005 the film of another novel, Three Dollars, told of a young Melbourne couple's courtship, marriage, then depression and financial disaster against the backdrop of the financial imperatives of Australia in the ' $80 \mathrm{~s}$ and ' $90 \mathrm{~s}$. When a reviewer identified the impetus for the Australian film The Bank as 'our desire to know what goes on inside boardrooms and on trading floors', he could have been speaking of any of these narratives (Martin, Age, 2001, 5). What made this 'desire to know' about the world of finance a plausible characterization of the general populace in Australia at the beginning of the $21^{\text {st }}$ century?

The answer is that by the new millenium the general populace had been caught up for some time in a finance culture that was more or less unrecognizable from the traditional world of the pre-1980s, and that had also moved on from the ordinary person's spectatorship of the changes, hubris, and finance celebrities of the '80s boom (Kitchener 1999, Toohey 1994). Finance culture - an amalgam of dispositions, ways of making sense, norms, routines and practices - had spread well beyond a narrow group of privileged players and had become an inescapable element in everyone's daily lives, installed in people's workplace and household habits as well as the habits of politicians and policy makers. Finance was no longer in the shadows. Its centrality to people's everyday was by now routinized. ${ }^{5}$ 
This changing finance culture in Australia is captured in the changing editorial policies and understandings at the daily The Australian Financial Review, part of the earlier specialist culture that has since had to navigate a broadened finance domain. Reading some of the editors' statements about what they thought the paper should be covering and, particularly, how they saw their readership, gives a sense of the shift in finance culture from, in the earlier period, something relevant only to 'elites' to, in the $21^{\text {st }}$ century, something explicitly engaging 'Australians' as a whole: 'In 1951', when the paper began, 'debate on economic policy was reserved primarily for the elite of society... Now Australians are among the most economically literate people in the world' (Ryan, Australian Financial Review, 16 August, 2001, 24). Expanding on this literacy - the ways of making sense that help comprise, along with practices such as buying and selling shares, a finance culture - another editor notes: 'a large proportion of the Australian public is now market literate as well as economically literate. The function of interest rates is widely understood, thousands of new investors have learned that shares can fall as well as rise and financial news is given wide coverage' (Sykes, Australian Financial Review, 16 August, 2001, 10-11). Michael Gill, 2001 editor-in-chief, puts his finger more particularly on the dispositions characteristic of present-day finance culture, when he identifies a steady path from the late 1970s which 'has seen individual interest and private choice become the driving forces in our lives' (Australian Financial Review, 16 August, 2001, 9). What had happened along that path, in the rhetoric embraced by an early '90s editor, was that the sharemarket had become 'democratized'. 'Everyone had become an investor-either directly on the sharemarket, or indirectly through their superannuation fund-and whole new industries, particularly in the financial services sector, had sprung up to cater to them' (Alexander, Australian Financial Review, 16 August, 2001, 7). The paper had a new audience to address, increasingly aware of the connection of their own lives to the finance sector. In 1996 when the Howard Coalition Government swept in, this 'steady path' accelerated. 'There was regulatory upheaval in financial markets—still recovering from the bond market crash — and an explosion of new investors through 
demutualization and privatization of monoliths such as the AMP, Commonwealth Bank and Telstra. It meant the Review had to be accessible to a vast new audience' (Light, Australian Financial Review, 16 August, 2001, 8). All in all, as the 2001 editor-in-chief of The Australian Financial Review says 'Over time, our "niche" in journalism has grown to almost mainstream activity' (Gill, 2001).

But striking as it may be, the notion of 'democratization' of the stock market is not adequate to understanding what has happened in the last decades. It did involve 'the Australian people' though, in particular ways.

\section{A Financialized 'We': Finance Rationality in Australia}

\footnotetext{
'So, let me get this straight. They're telling the public hourly every day, whether overall, on average, the price of the shares in all the publicly listed companies in the country has gone up or down?' Tanya asked in astonishment.

'Yep. That seems to be it.'

...Tanya predicted that the day would come when people would have difficulty remembering a time that movements in the stock market were not reported more frequently than the road toll or air pollution indices. She was right. The interminable repetition of sharemarket indices thereafter did not leave us unchanged. (Perlman 2005: 87-89)
}

This epigraph recounts the central characters in the novel Three Dollars discovering the national broadcaster's regular reporting of international and local stock market movements, one morning in 1985. The naturalization of a neoliberal focus on markets, described above, could have no better emblem than the routinization of share market news on Australian television and radio in the 1980s. Our argument is that the hegemony of global finance capital and its local Australian conditions and consequences has been achieved by these small things, as well as by legislative change and financial innovation. 
Regular media inscriptions of what some call a 'market logic' (Connell 2002: 8) and we describe as a finance rationality ${ }^{6}$ 'elaborat[e] and consolidat[e] what actually counts as society and how "what counts" gets incorporated and individuated in modes of behaviour and forms of identification and affiliation' (Mercer 1992: 31). However ephemeral and 'surface' media reportage, images, chat, dramatic or documentary narratives and so on may be, their continued inscribing of particular assumptions, cascading from one occasion to another, from print or online headline to radio talkback topic to television editorial to soap storyline to newspaper feature, help form what counts as Australian society. One such assumption, heavily inscribed since the late ' $80 \mathrm{~s}$, is the requirement to privately fund one's post-working life (superannuation) and that doing so is a self-evident and desirable ethos (being someone who has 'super'). ${ }^{7}$ Media coverage of finance and the repeated, persuasive and moralizing way media beckon people's attention to finance has helped produce and circulate a specific finance rationality with which the Australian population has been, over time, equipped - particular 'common sense' ways of knowing about 'the economy' in terms of finance, such as how you finance individual lifestyles, and the forms of calculation involved. The now potent cultural inscription of 'super' in Australian life (just as 'White Australia' once had potency ${ }^{8}$ ) works through immediate cultural recognition - as in this at once mundane and memorable full-page newspaper advertisement for the insurance and investment company Colonial First State (2004), presenting only a sparse checklist, going straight for the emotional jugular:

Yes, I want my super to perform.

No, I'd like to burden the kids.

Or see the inscription at work again in the Australian Government's (2005) advertisements for legislation enabling contributors to switch superannuation funds. An obligating injunction- 'Super Choice. Think about it because it's your future'- 
was coupled with a trio of apparently unbidden thought-bubbles from three representative individuals - 'It's my super.' 'It's my future.' 'It's my choice.' The exhortation by government and allied organizations for each Australian to acquire a libertarian disposition towards personal choice and autonomy is clear: self-finance your need for retirement income, and do so 'as if we were seeking to realise our own desires' (Rose 1990: 258). Shaping Australians as financially independent individuals has been central to neoliberal regimes of governance characterizing both Labor Governments (as a social neoliberalism) and Coalition Governments (in a more stringent neoliberalism) since the early 1980s. Australians have been 'formed and mannered' (Mercer 1992: 27) as a financialized 'we', ${ }^{9}$ possessors of an identity as shareholders or would-be shareholders, characterized by financial independence (or the struggle to attain it), seized by aspirations, and disposed to consider events as opportunities for investment. The finance rationality integral to this most recent governing of the Australian population is a relentlessly bourgeois way of knowing (defined by relations of ownership), organized in the terms of possessive individualism, made up of techniques of calculation and assumptions (for example, the neoclassical concept of 'waiting, ${ }^{10}$ ), and built around the notion of 'effortless enrichment', a disposition towards wealth creation through 'abstract flows of money' (Pryke and Allen 2000: 281). For many people this rationality has become the available way to assess situations and calculate their actions, 'making sense' in terms of finance opportunities, imperatives, verities (plan early plan often, diversify risk, move on). For those Australians without the economic capital to carry out these 'rational' and 'desirable' calculations, the finance rationality to which they have been exhorted through media, as well as through long-running government and other projects around financial literacy ${ }^{11}$ serves to underscore their exclusion from the norm.

Far from Australians leaping to own shares through their 'natural' greed, 'the only consistent human motivation' according to a literature that presents this allegedly 
universal trait as a foundation for capitalism (Schumaker, Weekend Australian Financial Review, 16-17 October, 2004, 31), this rationality has been used to shape people's agency in historically and culturally particular ways. It goes against, for example, a much longer-standing formation of the Australian 'people' as a yeomanry defined by the values of rural harmony and their distance from the money-power of the cities and their bankers. A populist demonization of banks was historically part of the Australian labour movement, especially its left, following the socioeconomic depression of the 1890 s, the role of financiers in WWI, the 1929 Wall Street stock market crash and consequent Great Depression, the popularity and tour of Henry George and his physiocratic idea of land as the source of all wealth (Love 1984).

In some ways, then, the role of finance in the ongoing formation and reformation of the 'Australian people' is nothing new. And the polar opposition of 'the banks' and 'the people' still figures in contemporary Australian media. The 2001 movie The Bank told a melodramatically clear parable of bank greed at the expense of and leading to resistance from 'ordinary people'. Similarly, veteran cartoonist Bruce Petty's regular work in News Corp and Fairfax broadsheets have also given Australians other tools with which to think about finance (Phiddian 2011). One of Petty's animated cartoons, the Finance episode of his Human Contraptions (2002) series screened on the national broadcaster, operates almost as a counter-text to more familiar televisual discussions of finance and globalization. Giving viewers a potted history of finance in the form of an Edenic creation story, Petty's is a quasi-marxist account: having initially 'invented money, a money exchange tube... and an operator who said he knew how to work itnow known as a banker', 'it is now humans circulating around a...tube for the convenience of finance.' Aired some five years before the GFC, the clear suggestion is that the contraption and the doctrinal faith that underpins it is outmoded. 
However, market populism (Frank 2001, du Gay 2008), the conceit of the 'market as us', has been by far the dominant mode of address of the past thirty years. It stretches from the nightly national television news commentary of the 1980 s where an influential finance commentator, Robert Gottleibsen, helped shape an understanding of finance relations and activity as something in which all Australians were somehow bound up-

Australia was hammered on two fronts today. Our stockmarket took yet another pasting and our dollar was crunched...Against other currencies we've had a real pasting...(ABC News, 1987)

- to the more recent, spectacularly successful advertising and publicity campaign run against a proposed mining tax (the Rudd Labor Government's Resource Super-Profits Tax, see Gilding et al 2012), in which the mining lobby, presenting as men of the people, shirt sleeves rolled up, spoke at once in the name of 'the global market', 'the national interest' and 'ordinary Australians.'

\section{From Normalized Culture to Rivalrous Projects?}

What is now publicly observable around the issue of 'finance' in Australia is a trio of different positions for citizens to take. ${ }^{12}$ as the normalized finance culture embedded through legislation, media promotion and attention, and organizational routines throughout the ' $80 \mathrm{~s}$, ' $90 \mathrm{~s}$ and early $21^{\text {st }}$ century has in the last few years been pressured, debated, and then got back to business as usual. We note disparate events and initiatives to indicate these three, more or less distinct, positions around finance currently on offer to Australian media audiences. They can be thought as three rivalrous projects for governing economic life: ongoing financialization, its reform, and less-developed programs for definancialization. ${ }^{13}$ 
The first indicative event is a recent finance hoax and responses to it. Consisting of a false press release sent out by an environmental activist to highlight concerns about a proposed mining development by Australian company Whitehaven Coal, the hoax headlined for several days. It 'caused Whitehaven shares to fall almost 9 per cent within minutes, wiping more than $\$ 300$ million off the value of the company' (Ker, Saturday Age, 12 January, 2013, 5). The actions of the hoaxer-described variously as a 'green prankster' (Manning, Age, 16 January, 2013), a 'young eco-lout' (Albrechtsen, Australian, 16 January, 2013, 10), a 'notorious anti-coal protester' (Sammut, Age, 15 January, 2013, 11), but also as “ "part of a long and proud history of civil disobedience"'(Greens Federal Senator Milne in Swan et al, Canberra Times, 8 January, 2013)— produced an investigation by the Australian Securities and Investment Commission (ASIC), concern from professional investors about copycat hoaxes (Ker and Hawthorne, Saturday Age, 12 January, 2013, 6-7), a call from Australia's stockmarket operator for Australian media to 'slow the speed at which digital sites are publishing news' in order to avoid market distortion (Ker 2013), and vociferous attacks by neoliberal opinion journalists and think-tank members on the hacker, Moylan, and his supporters (Albrechtsen 2013; Sammut 2013). A hoax which worked in effect to pluralize what counts as risk, pulling into view the 'externality' of climate change — and in being 'spectacularly successful in getting the issue of [its] prevention on our newspapers' front pages' (Wilson, Age, 11 January, 2013)—also received praise from high profile Green politicians and recasting from an act of criminal irresponsibility to a necessary 'creative subversion' and 'giv[ing] citizens a public voice' (Wilson 2013). As de Goede's (2005) genealogy of finance traced through many historical episodes, such skirmishes around policing the zone of 'the financial' registers an instability in regimes of finance, once again noticeable in Australian finance culture. 
Something similar is evident around a 2012 decision concerning the bellwether topic of superannuation. This time the 'policing' or issue of jurisdiction was sparked when a Productivity Commission's review recommended that Fair Work Australia, the Federal Government Industrial Relations tribunal, should decide on (the lucrative market of) default super funds. Under headlines such as 'Private super funds blast default review' (Yeates, Saturday Age, 31 October, 2012, 3), the CEO of the Financial Services Council representing private sector retail funds was quoted declaiming the decision as entrenching union-linked industry super funds: “ "Superannuation is not an industrial matter. [It] is a financial product and should not be adjudicated by Fair Work Australia"'(Brogden in Frost, Weekend Australian, 13-14 October, 2012a, 7). What is of interest here is a public struggle over the domain to which workers' wages - their compulsory super contribution — belong: industrial relations and the arbitration of a public tribunal, or a privatized finance sector?

There's a resonance here with the call to reinvigorate an industrial democracy agenda found in British writer Dan Hind's 'Jump! You Fuckers!' (2009), a piece which sits loosely within the definancialization project more explicitly advocated by Sassen in Open Democracy (2008), Amin (2011), and beginning to be registered in contrarian investment advice about future trends (for example, on financialsense.com, longvieweconomics.co.uk, dailyreckoning.com.au). The hallmark of this governmental project is a concerted challenge to the priority of the finance sector and finance criteria. This distinguishes it from a project for the reform of financialization, aimed at regulating the finance sector to avoid further failure of the system and so geared to less risky continuation and proliferation of the priority of finance. In Australia the reform project involves initiatives such as a proposed committed liquidity facility for Australian banks (ANZ 2012: 8), banning commissions on investments other than insurance and requiring financial planners to place clients interests ahead of their own (Martin 2010), and introducing measures to improve 
financial literacy, such as the chair of ASIC's bizarre proposal that potential investors pass an online exam before they buy 'complex or risky' products (Durkin, Australian Financial Review, 14 December, 2012, 1), as well as a plan to teach business and economics classes in Year 5 under the national curriculum proposed by the Australian Government (Rout, Australian, 9 January, 3).

And, as the name implies, a definancialization project is pitched directly against the still dominant project of financialization, which continues apace after some apparent faltering in 2008-09, and with growing assurance under the banner of austerity economic policies around the globe from 2010. In Australia moves towards austerity economics have taken the form of a renewed demand by employer organizations for changes to industrial relations in a struggle around the issue of productivity, and an Opposition-led demonization of government debt (the Rudd fiscal stimulus) and associated progressive taxation measures. The debate over the Whitehaven hoax and the consternation over the default super funds recommendation are two recent cultural moments that highlight the renewed advocacy and contemporary defence of financialization in Australia. The stridency of this defence can be read as a matter of concern for workers and those who rely on them and that, rival projects notwithstanding, the triumphalism of the early 2000s may not be far away.

\section{References}

ABC News. 1987. Finance Segment, 29 October, Australian Broadcasting Corporation.

Aglietta, Michel. 2000. Shareholder Value and Corporate Governance: A Comment and Some Tricky Questions. Economy and Society 29 (1): 146-59.

Aglietta, Michel and Régis Breton. 2001. Financial Systems, Corporate Control and Capital Accumulation. Economy and Society 30.4: 433-466.

Albrechtsen, Janet. 2013. Greens are Losing Voters as their Agenda is Exposed, Australian, 16 January, 10 .

Alexander, J. 2001. 'Returning the Newspaper to its Business Roots, Australian Financial Review, 16 August, Special Anniversary lift-out, 7.

Amin, Ash and Nigel Thrift, Nigel, eds. 2004. The Blackwell Cultural Economy Reader. Oxford: Blackwell.

Amin, Samir. 2011. Implosion of Contemporary Capitalism: Audacity, More Audacity in Formulating an Alternative to the Existing System. http://www.globalresearch.ca/implosion-of- 
contemporary-capitalism-audacity-more-audacity-in-formulating-an-alternative-to-theexisting-system $/ 28063$.

ANZ. 2012. Inquiry into the Post-GFC Banking Sector. ANZ Submission to the Senate Economics References Committee.

http://www.anz.com/resources/a/c/acc64d004dd99e0f85bfe52860a727f7/PostGFC banking.p df?CACHEID $=$ acc64d004dd99e0f85bfe52860a727f7

Australian Government. 2005. Super Choice advertisement, Australian Financial Review, 26 April, $12-13$.

Best, Jacqueline. 2005. The Limits of Transparency: Ambiguity and the History of International Finance. Ithaca, NY: Cornell UP.

Bourdieu, Pierre. 1979. Public Opinion Does Not Exist. In Communication and Class Struggle, Vol.1: Capitalism, Imperialism, edited by Armand Mattelart and Seth Sieglaub, 124-30. New York: International General.

Broadbent, John, Michael Palumbo and Elizabeth Woodman. 2006. The Shift from Defined Benefit to Defined Contribution Pension Plans-Implications for Asset Allocation and Risk

Management. Prepared for a Working Group on Institutional Investors, Global Savings and Assets. Bank for International Settlements. http://www.bis.org/publ/wgpapers/cgfs27broadbent3.pdf

Bryan, Dick, Randy Martin, Johanna Montgomerie and Karel Williams. 2012. An important failure: knowledge limits and the financial crisis. Economy \& Society 41 (3): 299-315.

Bryan, Dick and Michael Rafferty. 2006. Capitalism with Derivatives: A Political Economy of Financial Derivatives, Capital and Class. London: Palgrave Macmillan.

Callon, Michel. 1998. Introduction: the embeddedness of economic markets in economics. In The Laws of the Markets, edited by Michel Callon. Oxford: Blackwell.

Colebatch, Tim. 2010. Bravo, Australia, We Must Be a Miracle Economy, Age, 3 June. http://www.theage.com.au/opinion/politics/bravo-australia-we-must-be-a-miracle-economy20100602-wzq7.html

Colonial First State. 2004. Advertisement, Sunday Age, 14 November, 'Sunday Life' magazine.

Connell, R. W. 2002. Molloch Mutates: Global Capitalism and the Evolution of the Australian Ruling Class 1977-2002. Overland 167.

Du Gay, Paul. 2004. Against 'Enterprise' (but not against 'enterprise', for that would make no sense). Organization 11 (1): 37-57.

Flew, Terry. 2009. The cultural economy moment? Cultural Science 2 (1), [Online] Available at: http://cultural-science.org/journal/index.php/culturalscience/article/view/23/79

Froud, Julie, Sukhdev Johal, Adam Leaver, Michael Moran and Karel Williams. 2011. Groundhog Day: Elite Power, Democratic Disconnects and the Failure of Financial Reform in the UK. CRESC Working Paper Series. Working Paper No.108. http://www.cresc.ac.uk/publications/working-papers

Froud, Julie, Colin Haslam, Sukhdev Johal and Karel Williams. 2000. Shareholder value and financialization: consultancy promises, management moves. Economy \& Society 29 (1): pp. $80-110$.

Dean, Mitchell. 2009. The complexities of neo-liberalism, Australian Financial Review, 20 March, 45 .

de Goede, Marieke. 2005. Virtue, Fortune, and Faith: A Genealogy of Finance. Minneapolis: University of Minnesota Press.

du Gay, Paul. 2008. Keyser Süze Elites: Market Populism and the Politics of Institutional Change. The Sociological Review 56 (Special Issue Supplement 1): 80-102.

Durkin, Patrick. 2012. Investors Must Pass Exam: ASIC, Australian Financial Review, 14 December, 1.

Ewald, François. 1991. Insurance and Risk. In The Foucault Effect: Studies in Governmentality, edited by Graeme Burchell, Colin Gordon and Peter Miller. London: Harvester Wheatsheaf.

Federal Court of Australia. 2012. Wingecarribee Shire Council v Lehman Brothers Australia Ltd (in liq). http://images.smh.com.au/file/2012/09/21/3654617/Lehman.pdf?rand=1348212709058

Financial Review. 1971. Editorial, 1 April, 2.

Frost, James. 2012a. Super Review's Fair Work Plan Slammed, Weekend Australian, 13-14 October, 7. . 2012b. Just When you Thought There Were Enough Risks, A New Threat Rises, Weekend Australian, 27-28 October, Wealth 29.

Gibson Graham, J.K. 1996. The End of Capitalism (As We Knew It): A Feminist Critique of Political Economy. Oxford: Blackwell.

Gilding, Michael, Elizabeth Merlot, Shirley Leitch, Vikki Bunton and Lee Glezos. 2012. Media Framing of the Resources Super Profits Tax. Australian Journal of Communication 39 (3): 23-40.

Gill, M. 2001. The Future Rests on Solid Foundations, Australian Financial Review, 16 August, Special Anniversary lift-out, 9.

Glastris, Paul. 2005. Bush's Ownership Society. The Washington Monthly, December. http://www.washingtonmonthly.com/features/2005/0512.glastris.html

Gordon, Colin. 1991. Governmental Rationality: An Introduction. In The Foucault Effect: Studies in Governmentality, edited by Graeme Burchell, Colin Gordon and Peter Miller, 1-51. London: Harvester Wheatsheaf. 
Greenfield, Cathy and Peter Williams. 2001. Finance Advertising and Media Rhetoric. Southern Review: Communication, Politics \& Culture 34 (2): 44-66.

Hind, Dan. 2009. 'Jump! You Fuckers!' http://jumpyoufuckers.wordpress.com/

Hindess, Barry. 1988. Choice, Rationality, and Social Theory. London: Unwin Hyman.

Howard, John. 1999. Corporate Public Affairs Oration. http://pandora.nla.gov.au/nphwb/19991031130000/http://www.pm.gov.au/media/pressrel/1999/corppubaffairs2603.htm

Kelly, Paul. 1992. The end of certainty: The story of the 1980s. St. Leonard's, NSW: Allen \& Unwin.

Ker, Peter. 2013. Stock Exchange Pushes for Media Caution after Hoax, Saturday Age, 12 January, 5.

Ker, Peter and Hawthorne. 2013. Whitehaven a Siren Call for a Host of Hoaxes, Saturday Age, 12 January, Business Day 6.

Kitchener, Jennifer. 1999. Business Journalism in the 1980s. In Journalism: Print, Politics and Popular Culture edited by Ann Curthoys and Julianne Schultz. St Lucia, Qld: UQP.

Langley, Paul. 2008. The Everyday Life of Global Finance: Saving and Borrowing in Anglo-America. Oxford: OUP.

2002. World Financial Orders: An Historical International Political Economy. London: Routledge.

Latour, Bruno. 1990. Drawing Things Together. In Representation in Scientific Practice, edited by Michael Lynch and Steve Woolgar. Cambridge, MA: MIT Press.

Lewis, Michael. 1989. Liar's Poker: Rising Through the Wreckage on Wall Street. NY: W. W. Norton $\&$ Co.

Light, D. 2001. Behind Big Names Lurk Real Characters, Australian Financial Review, 16 August, Special Anniversary lift-out, 8.

Leyshon, Andrew and Nigel Thrift. 1997. Money/Space: Geographies of Monetary Transformation. London: Routledge,

Love, Peter. 1984. Labor and the Money Power: Australian Labour Populism 1890-1950. Melbourne: MUP.

MacKenzie, Donald. 2006. An Engine, Not a Camera: How Financial Models Shape Markets. Cambridge, MA: MIT Press.

Manning, Paddy. 2013. Don't Believe the Hype Over the Cost of Whitehaven, Age, 16 January, Business Day. http://www.theage.com.au/business/dont-believe-the-hype-over-the-cost-ofwhitehaven-hoax-20130115-2crh1.html

Mant, A. 2004. Australia Embraces an American Way, Sunday Age, 10 October: A09.

Martin, Adrian. 2001. Bankers behaving badly, Review of The Bank, Age, 6 September, Today 5.

Martin, Peter. 2010. An Epoch Ends. Financial Planners Won't Get Kickbacks. http://www.petermartin.com.au/2010/04/epoch-ends-financial-planners-wont-get.html

Martin, Randy. 2002. Financialization of Daily Life. Philadelphia, PA: Temple University Press.

Mercer, Colin. 1992. Regular Imaginings: The Newspaper and the Nation. In Celebrating the Nation: A Critical Study of Australia's Bicentenary, edited by Tony Bennett, Patrick Buckridge, David Carter and Colin Mercer. St Leonards: Allen \& Unwin.

Miller, Peter and Nikolas Rose. 2008. Governing Economic Life. In Governing the Present: Administering Economic, Social and Personal Life, 26-50. Cambridge: Polity.

Mitchell, Timothy. 2008. Rethinking Economy. Geoforum 39: 1116-21.

Parsons, Wayne. 1989. The Power of the Financial Press: Journalism and Economic Opinion in Britain and America. Aldershot, Hants: Edward Elgar.

Perlman, Elliot. 2005 [1998]. Three Dollars. Sydney: Picador.

Petty, Bruce. 2002. Human Contraptions. Television program. Directed by Bruce Petty. Produced with the assistance of the Australian Broadcasting Corporation. Distributed by Film Australia.

Phiddian, Robert. 2011. Bruce Petty Against the Rise of Market Rationalism. Communication, Politics \& Culture 44 (1): 60-77.

Pryke, Michael and John Allen. 2000. Monetized time-space: derivatives-money's 'new imaginary'? Economy \& Society 29 (2): 264-284.

Robinson, Joan and John Eatwell. 1973. An Introduction to Modern Economics. London: McGrawHill.

Rout, Milanda. 2013. Schools to Teach Business in Year 5, Australian, 9 January, 3.

Ryan, C. 2001.Discerning Readers Our Greatest Asset', Australian Financial Review, 16 August, Special Anniversary lift-out, 24.

Sammut, Jeremy. 2013. Coal Hoax Fails to Dig Deep Without a Martyr to the Cause, Age, 15 January, 11.

Sassen, Saskia. 2008. Too Big to Save: the End of Financial Capitalism. Open Democracy, 1 April. http:/www.opendemocracy.net/article/too-big-to-save-the-end-of-financial-capitalism-0

Schumaker, J. F. 2004. Greed: Capitalism's Necessary Evil, Weekend Australian Financial Review, 16-17 October, 31.

Shanahan, Dennis. 2000. Welcome to the Share Age, Age, 9 August, A13.

Swan, Jonathan, Judith Ireland and Damien Bright. 2013. Abetz Slams Greens for Backing Hoax. Canberra Times, 8 January. http://www.canberratimes.com.au/opinion/political-news/abetzslams-greens-for-backing-hoax-20130108-2cerk.html

Sykes, Trevor. 2001. Machinations of the Market Laid Bare, Australian Financial Review, 16 August, Special Anniversary lift-out, 10-11. 
Symons, Emma-Kate. 2010. Ailing France Praises Australian 'Miracle', Australian, 31 May. http://www.theaustralian.com.au/news/world/ailing-france-praises-australian-miracle/storye6frg6so-1225873201845

Symposium. 2009. The Rudd Essay \& The Global Financial Crisis, with Eric Hobsbawm, David Hale, Dean Baker, Charles R. Morris and John Gray; introduction by Robert Manne. The Monthly (45): 26-36.

Thrift, Nigel. 1998. Virtual capitalism: the globalisation of reflexive business knowledge. In Virtualism: A New Political Economy, edited by James Carrier \& Daniel Miller, 162-186. Oxford \& New York: Berg.

Thrift, Nigel. 2001. 'It's the romance, not the finance, that makes the business worth pursuing': disclosing new market culture. Economy and Society 30 (4): 412-32.

Toohey, Brian. 1994. Tumbling Dice: The Story of Modern Economic Policy. Port Melbourne: Reed Books.

Weekes, Peter. 2005. The Web Untangles the Art of Share Investing, Age, 30 April, Business 5.

Whimster, Sam and Leslie Budd. 1992. Introduction. In Global Finance and Urban Living: A Study of Metropolitan Change, edited by Sam Whimster and Leslie Budd. London: Routledge.

Williams, Karel. 2000. From shareholder value to present-day capitalism. Economy \& Society 29 (1): 1-12.

Wilson, Katherine. 2013. The Hoax We Had to Have, Age, 11 January. http://www.theage.com.au/opinion/society-and-culture/the-hoax-we-had-to-have-201301102cix 8.html.

Yeates, Clancy. 2012. Private Super Funds Blast Default Review, Saturday Age, 13 October, Business 3 .

\footnotetext{
${ }^{1}$ Though Pauline Hanson's right-wing populist One Nation Party gathered its momentum from concern over the impact on blue-collar workers and small farmers of opening the Australian economy to global competition.

${ }^{2}$ See Flew's (2009) useful account of the cultural economy 'moment' and need for greater knowledge of economics to avoid conflating actually various neoliberalisms into a monolithic ruling ideology.

${ }^{3}$ See Bryan et al (2012: 305-8) for critical appraisal of performativity and its limits.

${ }^{4}$ Such as the Mont Pelerin Society (Mitchell 2008: 1120).

${ }^{5}$ Martin (2002) describes this shift in the U.S. context.

${ }^{6}$ As Miller \& Rose include rationalities as elements in governing societies (2008) and Hindess (1988) stresses their plurality and contingent acquisition.

${ }^{7}$ In contradistinction to older models of social insurance where 'insurance...constitutes a mode of association which allows its participants to agree on the rule of justice they will subscribe to' (Ewald 1991: 207).

${ }^{8}$ The suggestion of the power involved borrows from Latour's (1990: 60) analysis of inscriptions and their use as part of his demonstration of how 'the weakest, by manipulating inscriptions of all sorts...become the strongest.'

${ }^{9}$ As in the newspaper article precede, 'We're more financially independent than ever' (Shanahan 2000).

10 'The growth of wealth involves in general a deliberate waiting for a pleasure which a person has (rightly or wrongly) the power of commanding in the immediate present' (A. Marshall in Robinson \& Eatwell 1973: 38).
} 
${ }^{11}$ Extending from a plethora of self-help bank websites, to subscriber seminars selling finance wisdom, to the Howard Government's establishment of a National Consumer and Financial Literacy Foundation (May 2005), to associated calls for embedding finance education in the school curriculum (Rout 2013).

12 'Take' in the strong sense used by Bourdieu (1979: 128), 'One commonly speaks of "taking a position"...the positions are there before us and we take them.'

${ }^{13}$ Projects in the sense of the objectives, knowledges and practices of loose alliances of actors (Miller and Rose 2008). 